\title{
Determinants of Ownership Structure: A Comparison of Common and Civil Law Countries
}

\author{
Ben Said Hatem ${ }^{1}$ \\ ${ }^{1}$ Faculty of Law, Economics and Management of Jendouba, University of Jendouba, Jendouba, Tunisia \\ Correspondence: Faculty of Law, Economics and Management of Jendouba, University of Jendouba, Jendouba, \\ Tunisia. E-mail: hatmbensaid@gmail.com
}

Received: May 11, 2014

doi:10.5539/ibr.v7n10p118
Accepted: September 5, $2014 \quad$ Online Published: September 25, 2014

URL: http://dx.doi.org/10.5539/ibr.v7n10p118

\begin{abstract}
The aim of this paper is to identify factors that explain ownership structure. Our empirical study uses two sample firms of two countries: Germany, characterized by a concentrated ownership structure, and the United Kingdom, characterized by diffused ownership structure. Our results show differences in the determinants of ownership structure between the two countries. Differences relate to size and research and development variables. Furthermore, profitability has no effect on the ownership structure for the two countries.
\end{abstract}

Keywords: ownership structure, diffused, concentrated, factors, size

\section{Introduction}

In line with the work of La Porta et al. (1997) and La Porta, Lopez -de- Silanes, and Shleifer (1999) which suggest that shareholder's protection degree significantly affects ownership concentration, as well as the work of Roe (2003) and Franks, Mayer, and Rossi (2003), in this paper we compare factors explaining ownership structure between Germany and United Kingdom. In our study, we distinguish between firms in Common Law countries (United Kingdom) which are characterized by strong protection of minority shareholders and firms in Civil Law Countries (Germany) which are characterized by low investor protection (Franks \& Mayer, 1995; La Porta, Shleifer \& Vishny, 2002). Weimer and Pape (1999) and Shleifer and Vishny, 1997 suggest that Germany and United Kingdom are characterized, respectively, by concentrated and diffused ownership structure. The rest of the work is structured as follows. Section 2 reviews the literature. Section 3 discusses our empirical methodology. The results are presented in Section 4. We make a sensitivity analysis of our results in Section 5. The last section summarizes our empirical results.

\section{Review of the Literature}

Based on the work of Demsetz and Lehn (1985), as well as the work of Hermalin and Weisbach (1988), Mak and Yuan (2001) study the determinants of ownership structure of firms in Singapore. The emphasis is on the effect of the board characteristics. In their models, the authors analyse the determinants of management ownership and capital share held by outside shareholders. Using a sample of 147 listed firms, the authors conclude a statistically significant effect of Board composition on ownership structure.

In a study in international context and based on the work of La Porta , Lopez -de- Silanes, Shleifer, and Vishny (1997), Van der Elst (2004) identifies factors explaining capital distribution of European firms. Using a sample of six European firms, Belgium, Italy, Spain, French, Germany and United KingDom, the empirical results show that ownership concentration is explained by sectors.

Referring to the work of La Porta et al. (1999), Bebchuk et al. (1999), and Wolfenzon (1999), Ungki and Chang Soo (2005) identify the determinants of ownership structure of Koreans firms. In their empirical validation, the authors use a sample of 6578 firms. Data on ownership structure are drawn from annual reports. The authors conclude that debt and size affect ownership structure.

However, the purpose of the article and Ansgar and Christian (2013) is similar to Van der Elst (2004). Indeed, the authors analyse the determinants of ownership concentration of public firms in an international context. With reference to the work of Faccio and Lang (2002), La Porta, Lopez de Silanes and Shleifer (1999), Thomsen and Pedersen $(1996,1997)$ suggest that shareholder's protection degree significantly affects ownership structure. Using a sample of 900 firms, the authors conclude that the factors explaining ownership concentration are 
significantly different between countries.

\section{The Methodology}

\subsection{Sample Selection}

In line with the work of Faccio and Lang (2002), Thomsen and Pedersen (1996, 1997), our sample consists of 100 firms from Germany (62 firms from service sector and 38 firms from manufacturing sector) and 100 firms from the UK (78 firms from service sector and 22 firms from manufacturing sector) for a period of nine years, from 2003 to 2011.

\subsection{Variables}

\subsubsection{The Dependant Variables}

Ownership structure: Jensen and Meckling (1976) and Singh and Harianto (1989) suggest that ownership structure can be described as an device of alignment of interests between managers and shareholders. We take as a measure of ownership structure, alternatively, capital shares held by the first, first two, first three, first four and top five controlling shareholders.

Herfindahl index: Based on the work of Demsetz and Lehn (1985), Jacelly, Maximiliano and Molina (2010), we measure ownership concentration by the Herfindahl index.

\subsubsection{The Independent Variables}

Debt ratio: Demsetz and Lehn (1985) support a significant relationship between debt and ownership structure. Debt ratio is calculated as Long term debt over Shareholder funds. Debt and ownership structure can be considered as substitutable tools to control managers' opportunistic behaviour. The expected influence of this variable is negative. Hypothesis 1: debt negatively affects ownership structure.

Firm size: Based on the work of Demsetz and Lehn (1985), we try to measure the impact of firm size on ownership structure. Firm size ratio is calculated as natural log of sum of market value of equity and long term debt. Julio and Torre (2006) argue that the larger firm size is, the more costly it is for insiders and outsiders to increase their part in the capital of these firms. Hypothesis 2: there is a negative interdependence between firm size and ownership structure.

Growth opportunities: In line with the work of La Porta, Shleifer and Vishny (2002), we measure the impact of growth opportunities on ownership concentration by Tobin's $Q$ ratio (Tobin's $Q$ ratio equal to the sum of market capitalisation and long term debt over total assets). Highest growth opportunities convey a signal on the firm's financial and economic health. In this case, managers, or external investors are stimulated to increase their ownership structure to take advantage. Hypothesis 3: growth opportunities positively affect ownership structure.

Research and development: similar to the work of Thomsen and Pedersen (1998) and Bong Geul Chun (2009), we examine the effect of research and development expenditure on the capital distribution of European firms. The ratio is measured by research and development expenditures over total sales. A high value of research and development spending will limit the firm's debt ratio. In the case of a positive relationship between debt and ownership structure, we recorded a negative effect of research and development expenses on external shareholdings. Hypothesis 4: there is a negative relationship between research and development spending and ownership structure.

Return on equity: similar to the work of Victoria Krivogorsky (2006), we measure firm performance by return on equity ratio calculated as net income to shareholders funds. A high value of this ratio indicates that the firm is more profitable. Investors always try to benefit by increasing their holdings. Hypothesis 5: there is a positive interdependence between return on equity and ownership structure.

Firm age: according to the work of Mak and Yuan (2001), we consider in our article the role of firm age in explaining ownership structure of European firms. Older firms are more recognized than younger firms. Therefore, investors will be encouraged to hold a high proportion of capital. Hypothesis 6: there is a positive interdependence between firm age and ownership structure.

Activity sectors: according to the work of Denis and Sarin (1999), Thomsen and Pedersen (1998), Van der Elst (2004), we look into the role of activity sectors in explaining ownership structure determinants.

\subsection{The Models}

To analyze differences in determinants of ownership structure between the U.K and Germany, and following the methodology developed by Themistokles, Evaggelos and Koufopoulos (2009), we test the following models: 


$$
\begin{aligned}
& O W N 1_{i t}=\beta_{0}+\beta_{1} \text { DebtRatio }_{i t}+\beta_{2} \text { SIZE }_{i t}+\beta_{3} \text { Growth }_{i t}+\beta_{4} R D_{i t}+\beta_{5} R O E_{i t}+\beta_{6} \text { Age }_{i t}+\varepsilon_{i t} \\
& \text { SUM }_{i t}=\beta_{0}+\beta_{1} \text { DebtRatio }_{i t}+\beta_{2} \text { SIZE }_{i t}+\beta_{3} \text { Growth }_{i t}+\beta_{4} R D_{i t}+\beta_{5} R O E_{i t}+\beta_{6} \text { Age }_{i t}+\varepsilon_{i t} \\
& \text { SUM }_{i t}=\beta_{0}+\beta_{1} \text { DebtRatio }_{i t}+\beta_{2} \text { SIZE }_{i t}+\beta_{3} \text { Growth }_{i t}+\beta_{4} R D_{i t}+\beta_{5} R O E_{i t}+\beta_{6} \text { Age } i t+\varepsilon_{i t} \\
& \text { SUM }_{i t}=\beta_{0}+\beta_{1} \text { DebtRatio }_{i t}+\beta_{2} \text { SIZE }_{i t}+\beta_{3} \text { Growth }_{i t}+\beta_{4} R D_{i t}+\beta_{5} \text { ROE }_{i t}+\beta_{6} \text { Age }_{i t}+\varepsilon_{i t} \\
& \text { SUM }_{i t}=\beta_{0}+\beta_{1} \text { DebtRatio }_{i t}+\beta_{2} \text { SIZE }_{i t}+\beta_{3} \text { Growth }_{i t}+\beta_{4} R D_{i t}+\beta_{5} \text { ROE }_{i t}+\beta_{6} \text { Age }_{i t}+\varepsilon_{i t} \\
& H_{i t}=\beta_{0}+\beta_{1} \text { DebtRatio }_{i t}+\beta_{2} \text { SIZE }_{i t}+\beta_{3} \text { Growth }_{i t}+\beta_{4} R D_{i t}+\beta_{5} R O E_{i t}+\beta_{6} A g e_{i t}+\varepsilon_{i t}
\end{aligned}
$$

\section{Discussion of the Results}

\subsection{Descriptive Statistics}

The results are presented in Table 1. According to the work of Van der Elst (2004), the results indicate a low ownership concentration structure as measured by the Herfindahl index in the UK unlike Germany. Similar to Franks et al. (2008), ownership concentration equal to 5,76\% for the UK and 35,7\% for the Germany. This result implies that minority shareholders in the UK are protected by law, which will lead to a low degree of ownership concentration. This result holds for different measures of ownership structure, especially from the first until the first five controlling shareholders. The United King Dom firms are more indebted and younger than firms in Germany (an average debt of 0.678 and an average age of 33.922). Mak and Yuan (2001) find an average age of 12,83 for Singapore firms. Descriptive statistics show, too, that the firms in the UK have higher size and higher growth opportunities. We find an average value of Tobin's Q of 1,235 for the UK (this value is very close to that found by Basil and Taylor, 2008: an average value of Market To Book ratio equal to 1,1405). Similarly, the UK firms are more profitable than the German firms. Low-profitable firms do not prevent German managers to spend significant amounts of cash in research and development activities (about 0.0423 to 0.0221 compared to UK firms).

\subsection{Presentation of the Results}

The results are presented in Table 2. Our models are statistically significant and explain between $8,37 \%$ and $52,42 \%$ of ownership structure.

Debt ratio: As suggested by Bae et al. (2002), Joh (2003), Baek et al. (2006), the empirical results indicate that debt positively and significantly affects ownership structure variables measured by the first five controlling shareholders for the UK and the first four controlling shareholders and the Herfindhal Index for Germany. This result means that, in these two countries, debt and ownership structure is two complementary tools to control managers' opportunistic behaviour. This result reject hypothesis 1 .

\begin{tabular}{|c|c|c|c|c|c|c|c|c|c|c|}
\hline & \multicolumn{4}{|c|}{ United Kingdom } & \multicolumn{6}{|c|}{ Germany } \\
\hline & OBS & MEAN & STD DEV & MIN & MAX & OBS & MEAN & STD DEV & MIN & MAX \\
\hline OWN1 & 506 & 0,168 & 0,161 & 0,0004 & 0,8326 & 513 & 0,569 & 0,225 & 0,0011 & 0,995 \\
\hline SUM2 & 591 & 0,210 & 0,186 & 0,0004 & 0,924 & 551 & 0,626 & 0,269 & 0,00400 & 0,999 \\
\hline SUM3 & 641 & 0,238 & 0,196 & 0,0004 & 0,935 & 561 & 0,600 & 0,290 & 0,00400 & 0,999 \\
\hline SUM4 & 669 & 0,268 & 0,203 & 0,0015 & 0,967 & 564 & 0,594 & 0,304 & 0,00390 & 0,999 \\
\hline SUM5 & 684 & 0,292 & 0,216 & 0,0021 & 0,994 & 550 & 0,592 & 0,305 & 0,002 & 0,999 \\
\hline $\mathrm{H}$ & 684 & 0,0576 & 0,0971 & $4,41 \mathrm{E}-6$ & 0,693 & 664 & 0,357 & 0,264 & $4 \mathrm{E}-6$ & 0,991 \\
\hline Debt ratio & 800 & 0,678 & 2,190 & $5,75 \mathrm{E}-6$ & 34,213 & 842 & 0,465 & 1,251 & 0,0000620 & 24,545 \\
\hline size & 820 & 22,457 & 1,507 & 16,441 & 26,016 & 821 & 21,808 & 1,526 & 18,957 & 25,652 \\
\hline Tobin Q & 820 & 1,235 & 0,829 & 0,183 & 11,370 & 820 & 0,9815 & 1,503 & 0,0682 & 19,865 \\
\hline$R \& D$ & 324 & 0,0221 & 0,0696 & 0,0000379 & 0,606 & 324 & 0,0423 & 0,0385 & 0,000602 & 0,190 \\
\hline ROE & 839 & 0,0967 & 0,160 & $-0,865$ & 0,931 & 851 & 0,0674 & 0,100 & $-0,903$ & 0,945 \\
\hline Age & 835 & 33,922 & 35,112 & 1 & 125 & 827 & 56,154 & 47,962 & 1 & 171 \\
\hline
\end{tabular}

Firm size: Similar to the results of Thomsen and Pedersen (1996), the impact of firm size in the UK is negative but statistically non-significant. However, in Germany, we find the same sign, but at the $10 \%$ significance level for "H" and "OWN1". This result confirms our second hypothesis and indicates that with the increase in firm size, it becomes very difficult for investors to increase their holdings.

Table 1. Descriptive statistics 
Table 2. Determinants of ownership structure

\begin{tabular}{|c|c|c|c|c|c|c|c|c|c|c|c|c|}
\hline & \multicolumn{6}{|c|}{ United King Dom } & \multicolumn{6}{|c|}{ Germany } \\
\hline & OWNI & SUM2 & SUM3 & SuM4 & SUM5 & $\mathrm{H}$ & OWNI & SUM2 & SUM3 & SUM4 & SUM5 & $\mathrm{H}$ \\
\hline $\mathrm{C}$ & 0,106 & $-0,207$ & $-0,779$ & $-1,0198^{*}$ & $-1,0389^{*}$ & 0,0985 & $2,230 * *$ & $-1,876$ & $-1,211$ & 0,975 & 0,599 & $2 ., 226$ \\
\hline Debt ratio & $-0,00735$ & $-0,000117$ & 0,0196 & 0,0191 & $0,0400^{*}$ & 0,0127 & $-0,0122$ & $-0,0580$ & 0,0414 & $0,295^{*}$ & 0,195 & $0,287 * *$ \\
\hline size & $-0,0104$ & $-0,0323$ & $-0,0279$ & $-0,0252$ & $-0,0399$ & $-0,0201$ & $-0,085 I^{*}$ & 0,0524 & 0,000261 & $-0,147$ & $-0,126$ & $-0,173^{*}$ \\
\hline Tobin Q & 0,00623 & 0,0142 & 0,0274 & 0,0333 & $0,0528 *$ & 0,0175 & $0,0623 * *$ & 0,0646 & 0,0563 & $0,108 *$ & 0,0945 & $0,152 * * *$ \\
\hline$R \& D$ & $-0,00475$ & 0,106 & 0,253 & 0,417 & 0,635 & 0,186 & $-5,442 * * *$ & 0,237 & 3,232 & 1,758 & 1,573 & 0,646 \\
\hline ROE & $-0,00819$ & 0,0209 & 0,0136 & 0,00303 & $-0,0203$ & 0,0248 & $-0,219$ & $-0,0675$ & $-0,175$ & $-0,0800$ & $-0,283$ & $-0,111$ \\
\hline Age & $0,00757 * * *$ & $0,0279 * * *$ & $0,0393 * * *$ & $0,0450 * * *$ & $0,0540 * * *$ & $0,0986 * * *$ & 0,00690 & $0,0232^{*}$ & $0,0294 * *$ & $0,0480 * * *$ & $0,0479 * * *$ & $0,0321 * * *$ \\
\hline R Squared (\%) & 11,69 & 27,31 & 39,82 & 46,58 & 52,42 & 13,58 & 8,37 & 10,71 & 12,28 & 14,41 & 15,66 & 9,46 \\
\hline Chix Deux & 3,07 & 10,33 & 19,85 & 27,03 & 35,07 & 5 & 2,18 & 2,98 & 3,45 & 4,26 & 4,58 & 3,05 \\
\hline
\end{tabular}

Growth opportunities: Differently to Mak and Yuan (2001), we record a positive and statistically significant effect of growth opportunities in the UK on the "SUM 5" variable only. Similarly, we find this same effect in Germany for the "OWN 1", "SUM 4" and "H" variables. This result indicates that high growth opportunities convey a good signal on the future perspective of firms. External Investors seek a profitable investment of their funds, and will increase, consequently, their shareholdings in these companies. This result validates our hypothesis 3.

Research and development: Similar to Zeckhouser and Pound (1990) and Thomsen and Pedersen (1998), the test of the model shows that the variable research and development negatively and significantly affects capital share owned by the controlling shareholder, only, for Germany. This result means that a high ratio of R\&D decreases the amount of cash in the hands of managers, and moderates their power. It is not therefore necessary to increase ownership structure of outsiders to control managers' opportunistic behaviour. This result validates our hypothesis 4.

Return on equity: The empirical results show that profitability does not significantly affect ownership structure in the two countries: United Kingdom and Germany. This result indicates that investors do not take into account firms profitability to decide to increase their holdings. This result rejects our hypothesis 5 .

Firm age: The age variable has a positive and statistically significant in both countries for all alternative measures of ownership structure, except for the "OWN1" variable in Germany. This result suggests that investors always try to increase their holdings in the most recognized firms. Indeed, older firms can transmit a signal on the security of their funds placement. This result confirms our Hypothesis 6.

\section{The Sensitivity Analysis}

The results are presented in Table 3. Similar to Demsetz and Lehn (1985), Bergstrom and Rydqvist (1990), Van der Elst (2004), we analyze the effect of activity sectors on ownership structure determinants. To this effect, we compare between Common Law and Civil Law countries. Sensitivity analysis is maked using two measures of ownership structure: the first four and top five controlling shareholders. For the UK, the empirical results indicate that debt and ownership structure are two substitutable tools for controlling managers' opportunistic behaviours in the industrial sector (unlike industrial firms in Germany). Moreover, for the service sector, we find a positive and statistically significant effect of debt on the capital share held by the top five controlling shareholders. Contrary to previous results, we find a positive effect of firm size for the service sector in Germany. Similarly, we find a negative and statistically significant effect of growth opportunities for manufacturing firms in the UK. The results for research and development expenditure do not confirm our research hypothesis for the service sector in the UK and industrial sector in Germany. However, a positive and statistically significant effect of profitability is found only in the industrial sector in Germany. The results of the age variable remain unchanged. 
Table 3. Role of activity sectors in determinants of ownership structure

\begin{tabular}{|c|c|c|c|c|c|c|c|c|}
\hline & \multicolumn{4}{|c|}{ United King Dom } & \multicolumn{4}{|c|}{ Germany } \\
\hline & $\begin{array}{l}\text { SUM4 } \\
\text { Service }\end{array}$ & $\begin{array}{l}\text { SUM5 } \\
\text { Service }\end{array}$ & $\begin{array}{l}\text { SUM4 } \\
\text { manufacturing }\end{array}$ & $\begin{array}{l}\text { SUM5 } \\
\text { manufacturing }\end{array}$ & $\begin{array}{l}\text { SUM4 } \\
\text { Service }\end{array}$ & $\begin{array}{l}\text { SUM5 } \\
\text { Service }\end{array}$ & $\begin{array}{l}\text { SUM4 } \\
\text { manufacturing }\end{array}$ & $\begin{array}{l}\text { SUM5 } \\
\text { manufacturing }\end{array}$ \\
\hline $\mathrm{C}$ & 0,517 & 0,640 & $-0,496$ & $-3,345^{* * *}$ & $-1,677$ & $-1,906^{*}$ & 2,226 & 3,0291 \\
\hline Debt ratio & 0,0248 & $0,0436^{*}$ & $-0,202^{*}$ & $-0,230^{*}$ & $-1,149$ & $-0,260$ & $0,447^{*}$ & $0,367^{*}$ \\
\hline size & $-0,0844^{* * *}$ & $-0,103^{* * *}$ & 0,0405 & 0,0773 & $0,115^{*}$ & $0,128^{* *}$ & $-0,285^{*}$ & $-0,347^{*}$ \\
\hline Tobin Q & $0,103^{* * *}$ & $0,129^{* * *}$ & $-0,0843^{*}$ & $-0,105$ & 0,0330 & 0,0130 & 0,0827 & 0,0981 \\
\hline $\mathrm{R} \& \mathrm{D}$ & $0,653^{*}$ & $0,868^{*}$ & $-2,0750$ & $-0,499$ & $-2,587$ & $-2,685^{*}$ & $7,168^{*}$ & $8,579^{* *}$ \\
\hline ROE & 0,0500 & 0,0278 & $-0,374$ & $-0,195$ & $-1,585^{* * *}$ & $-1,538^{* * *}$ & $0,672^{*}$ & 0,530 \\
\hline Age & $0,0587^{* * *}$ & $0,0688^{* * *}$ & 0,00121 & $0,0369^{* * *}$ & $-0,00158$ & $-0,00188$ & $0,0630^{* * *}$ & $0,0724^{* * *}$ \\
\hline R Squared (\%) & 63,04 & 66,26 & 4,51 & 42,06 & 43,78 & 44,89 & 21,97 & 25,07 \\
\hline Chix Deux & 30,14 & 35,35 & 10,01 & 9,32 & 14,17 & 16,03 & 3,94 & 4,57 \\
\hline
\end{tabular}

${ }^{*},{ }^{* * * * *}:$ significance at $10 \%, 5 \%$ and $1 \%$ levels respectivel.

\section{Conclusion}

Laporta, Shleifer and Vishny (2002) emphasize that most countries have different degrees of legal shareholders protection. Moreover, these different protection degrees will result in two types of ownership structure: concentrated and diffused ownership structures (La Porta and al, 1998, 1999, Claessens, Djankov, and Lang, 2002). Therefore, we are led to study the differences in the determinants of ownership structure between Germany and the United King Dom. The empirical results show differences in firm size and research and development spending. However, the effect of the variable "ROE" is not significant for the two countries.

\section{References}

Al-Najjar, B., \& Peter, T. (2008). The relationship between capital structure and ownership structure. Managerial Finance, 34(12), 919-933. http://dx.doi.org/10.1108/03074350810915851

Ansgar, R., \& Christian, W. (2013). Determinants of ownership concentration in public firms: The importance of firm, industry and country-level factors. International Review of Law and Economics, 33, 1-14. http://dx.doi.org/10.1016/j.irle.2012.08.003

Bae, K., Kang, J., \& Kim, J. (2002). Tunneling or value added? Evidence from mergers by Korean business groups. Journal of Finance, 57, 2695-2740. http://dx.doi.org/10.1111/1540-6261.00510

Baek, J., Kang, J., \& Lee, I. (2006). Business groups and tunneling: evidence from private securities offerings by Korean chaebols. Journal of Finance, 61, 2415-2449. http://dx.doi.org/10.1111/j.1540-6261.2006.01062.x

Bebchuk, L., Kraakman, R., \& Triantis, G. (1999). Stock pyramids, cross-ownership, and dual class equity: The creation and agency costs of separating control from cash flow rights. Discussion Paper \#249, Harvard LawSchool.

Bergstrom, C., \& Rydqvist, K. (1990). The determinants of corporate ownership: An empirical study on Swedish data. Journal of Banking and Finance, 14(2/3), 237-253. http://dx.doi.org/10.1016/0378-4266(90)90048-7

Bong, G. C. (2009). Firm's choice of ownership structure: An empirical test with Korean multinationals. Japan and the World Economy, 21(2009), 26-38. http://dx.doi.org/10.1016/j.japwor.2007.08.001

Claessens, S., Simeon, D., Joseph, F., \& Larry, L. (2002). Expropriation of minority shareholders in East Asia. Journal of Finance, 57.

Demsetz, H., \& Lehn, K. (1985). The structure of corporate ownership: causes and consequences. Journal of Political Economy, 93, 1155-1177. http://dx.doi.org/10.1086/261354

Denis, D. J., \& Sarin, A. (1999). Ownership and board structures in publicly traded corporations. Journal of Financial Economics, 52(2), 187-223. http://dx.doi.org/10.1016/S0304-405X(99)00008-2

Faccio, M., \& Lang, L. H. P. (2002). The ultimate ownership of Western European corporations. Journal of Financial Economics, 65(3), 365-395. http://dx.doi.org/10.1016/S0304-405X(02)00146-0 
Franks, J. R., Mayer, C., Volpin, P. F., \& Wagner, H. F. (2008). Evolution of Family Capitalism: A Comparative Study of France, Germany, Italy and the UK. AFA 2009 San Francisco Meetings Paper. Retrieved from http://ssrn.com/abstract=1102475

Franks, J., \& Mayer, C. (1995). Ownership and Control. In Siebert (Ed.), Trends in Business Organization: Do Participation and Co-operation Increase Competitiveness? JCB Mohr: Tubingen.

Franks, J., Mayer, C., \& Rossi, S. (2003). The origination and evolution of ownership and control. ECGI Finance Working Paper no. 09/2003.

Hermalin, B. E., \& Weisbach, M. S. (1988). The determinants of board composition. Rand Journal of Economics, 19, 589-605. http://dx.doi.org/10.2307/2555459

Jacelly, C., Maximiliano, G., \& Carlos, A. M. (2010). Ownership and capital structure in Latin America. Journal of Business Research, 63(2010), 248-254. http://dx.doi.org/10.1016/j.jbusres.2009.03.010

Jensen, M. C., \& Meckling, W. H. (1976). Theory of the firm: managerial behaviour, agency costs and ownership $\begin{array}{llll}\text { structure. Journal of } & \text { Financial 305-360. }\end{array}$ http://dx.doi.org/10.1016/0304-405X(76)90026-X

Joh, S. W. (2003). Corporate governance and firm profitability: evidence from Korea before the economic crisis. Journal of Financial Economics, 68, 287-322. http://dx.doi.org/10.1016/S0304-405X(03)00068-0

Julio, P., \& Chabela, De La T. (2006). The Role of Investment, Financing and Dividend Decisions in Explaining Corporate Ownership Structure: Empirical Evidence from Spain. European Financial Management, 12(5), 661-687. http://dx.doi.org/10.1111/j.1468-036X.2006.00272.x

La Porta, R., Lopez-de-Silanes, F., Andrei, S., \& Robert, W. V. (1998). Law and finance. Journal of Political Economy, 106, 1113-1155. http://dx.doi.org/10.1086/250042

La porta, R., Lopez-de-silanes, F., Andrei, S., \& Vishny investor, R. (2002). Protection and corporate valuation. Journal of Finance, (3).

La Porta, R., Lopez-de-Silanes, F., Shleifer, A., \& Vishny, R. (1997). Legal determinants of external finance. Journal of Finance, 52, 1131-1150. http://dx.doi.org/10.1111/j.1540-6261.1997.tb02727.x

La Porta, R., Lopez-de-Silanes, F., Shleifer, A., \& Vishny, R. (1999). Corporate ownership around the world. Journal of Finance, 54, 471-517. http://dx.doi.org/10.1111/0022-1082.00115

Mak. Y. T., \& Yuan, L. (2001). Determinants of corporate ownership and board structure: evidence from Singapore. Journal of Corporate Finance, 7, 235-256.

Roe, M. (2003). Political determinants of corporate governance. Oxford: Oxford University Press.

Shleifer, A., \& Vishny, R. (1997). A survey of corporate governance. Journal of Finance, 52, 737-783. http://dx.doi.org/10.1111/j.1540-6261.1997.tb04820.x

Singh, H., \& Harianto, F. (1989a). Top management tenure, corporate ownership structure and the mangnitude of golden parachuts. Strategic Management Journal, 10, 143-156.

Singh, H., \& Harianto, F. (1989b). Management-board relationships, takeover risk and adoption of golden para-chutes. Academy of Management Journal, 32, 7-24. http://dx.doi.org/10.2307/256417

Themistokles, L., Evaggelos, D., \& Koufopoulos, D. (2009). Ownership Structure in Greece: Impact of Corporate Governance. Journal of Corporate Governance, 8(3/4), 75-90.

Thomsen, S., \& Pedersen, T. (1996). Nationality and ownership structures: The 100 largest companies in six European nations. Management International Review, 36(2), 149-166.

Thomsen, S., \& Pedersen, T. (1997). European patterns of corporate owner-ship: A twelve country study. Journal of International Business Studies, 28(4), 759-778. http://dx.doi.org/10.1057/palgrave.jibs.8490118

Thomsen, S., \& Pedersen, T. (1998). Industry and ownership structure. International Review of Law \& Economics, 18(4), 386-404. http://dx.doi.org/10.1016/S0144-8188(98)00022-2

Ungki, L., \& Chang-Soo, K. (2005). Determinants of ownership structure: An empirical study of the Korean conglomerates. Pacific-Basin Finance Journal, 13(2005), 1-28. http://dx.doi.org/10.1016/j.pacfin.2003.11.001

Van der Elst, C. (2004). Industry-specificities and size of corporations: Determinants of ownership structures. International Review of Law and Economics, 24(4), 425-446. http://dx.doi.org/10.1016/j.irle.2005.01.003 
Victoria, K. (2006). Ownership, board structure, and performance in continental Europe. The International Journal of Accounting, 41, 176-197. http://dx.doi.org/10.1016/j.intacc.2006.04.002

Weimer, J., \& Pape, J. (1999). A Taxonomy of Systems of Corporate Governance. Corporate Governance: An International Review, 7(2), 152-166. http://dx.doi.org/10.1111/1467-8683.00143

Wolfenzon, D. (1999). A theory of pyramidal ownership. Mimeo, Harvard University.

Zeckhouser, R., \& Pound, J. (1990). Are large shareholders effective monitors? An investigation of share ownership and corporate performance. In G. R. Hub-bard (Ed.), Asymmetric information, corporate finance and investment. Chicago: University of Chicago Press.

\section{Copyrights}

Copyright for this article is retained by the author(s), with first publication rights granted to the journal.

This is an open-access article distributed under the terms and conditions of the Creative Commons Attribution license (http://creativecommons.org/licenses/by/3.0/). 